\title{
Impact of COVID-19 and associated lockdown on livestock and poultry sector in
} Nigeria

${ }^{*}$ Akure, C. O. ${ }^{* 3}$ Vantsawa, P. A.,${ }^{4}$ Balogun, S. O. ${ }^{4}$ Omodona, S., ${ }^{4}$ Emeghara, U. U. and ${ }^{4}$ Olafemi, S. O.

${ }^{2}$ National Animal Production Research Institute, Ahmadu Bello University, Zaria

${ }^{3}$ Department of Biological Sciences, Nigerian Defence Academy, Kaduna

${ }^{4}$ Federal College of Forestry and Mechanization, Afaka, Kaduna

"Corresponding author: akurechristy@yahoo.com

Abstract

The COVID-19 pandemic and the associated lockdown for a long period have created a significant adverse impact on different sectors, including that of the agriculture and other allied sub-sectors in Nigeria. The present research was aimed at depicting the impact of this pandemic and the lock down on the poultry sectors in the Nigeria, which has been one of the fastest growing sectors in recent years. Inadequacy of country-wide information has been a major problem for having a thorough understanding of the impact onthe prolonged lockdown on different sub-sectors of livestock and poultry. In the present case, an in-depth, analysis of the subject has been made through the collation of primary data. The paper highlights various dimensions of the impacts, namely, reduction in the demand of different commodities, wastage of the produce due to the closure of transport and market chains, distress sale of the produce, and labour shortage and recommendations for revival strategies. The present impact study although gives a picture about the overall scenario in faggae local government area, a systematic study through the collection of primary data from all over the country is suggested, which will provide a holistic view of the impact on each of the sub-sectors and the associated value chains. The vast majority of poultry farmers in the world including Nigeria were adversely affected with the covid-19 pandemic, as a result of the deadly effect of the pandemic which brought about the enforcement of lockdown in order to cub the effect of the spread of this virus. This study examined the impact of covid-19 on the poultry production in faegea local government area of kano state. Primary data were used for the study. A multi stage sampling technique was used to select two hundred poultry farmers. Descriptive statistics and likert scale were used to achieve the stated objectives. The socio-economic characteristics indicate that the respondents have a mean age of 29 years with $58 \%$ aged between 21-30 years. About sixty-eight (68\%) of the respondents were males, 74\% were married while the total \% of people with primary, secondary and tertiary education were about $98 \%$. An average household had about five persons in the study area.

Keywords: COVID-19, pandemic, value chain, poultry subsector, distress sale

\section{Impact du COVID-19 et du confinement associé sur le secteur de l'élevage et de la} volaille au Nigéria

\section{Résumé}

La pandémie COVID-19 et le confinement associé pendant une longue période ont créé un impact négatif significatif sur différents secteurs, y compris celui de l'agriculture et d'autres sous-secteurs connexes au Nigeria. La présente recherche visait à décrire l'impact de cette pandémie et du verrouillage sur les secteurs de la volaille au Nigéria, qui a été l'un des secteurs à la croissance la plus rapide ces dernières années. L'insuffisance des informations à l'échelle du pays a été un problème majeur pour avoir une compréhension approfondie de 


\section{Impact of COVID-19 and associated lockdown on livestock and poultry sector}

l'impact du confinement prolongé sur les différents sous-secteurs de l'élevage et de la volaille. Dans le cas présent, une analyse approfondie du sujet a été effectuée à travers la collecte de données primaires. Le document met en évidence diverses dimensions des impacts, à savoir la réduction de la demande de différents produits, le gaspillage des produits en raison de la fermeture des chaînes de transport et de marché, la vente de détresse des produits, la pénurie de main-d'œuvre et des recommandations pour des stratégies de relance. Bien que la présente étude d'impact donne une image du scénario global dans la zone de gouvernement local de faggae, une étude systématique à travers la collecte de données primaires de tout le pays est suggérée, ce qui fournira une vue holistique de l'impact sur chacun des sous-secteurs et les chaînes de valeur associées. La grande majorité des éleveurs de volailles dans le monde, y compris le Nigéria, a été affectée négativement par la pandémie de covid-19, en raison de l'effet mortel de la pandémie qui a entraîné l'application du confinement afin de réduire l'effet de la propagation de ce virus. . Cette étude a examiné l'impact du covid-19 sur la production de volaille dans la région du gouvernement local de Faegea, dans l'État de Kano. Les données primaires ont été utilisées pour l'étude. Une technique d'échantillonnage à plusieurs degrés a été utilisée pour sélectionner deux cents éleveurs de volaille. Des statistiques descriptives et une échelle de likert ont été utilisées pour atteindre les objectifs énoncés. Les caractéristiques socio - économiques indiquent que les répondants ont un âge moyen de 29 ans avec 58\% entre 21 et 30 ans. Environ soixante-huit (68\%) des répondants étaient des hommes, $74 \%$ étaient mariés, tandis que le pourcentage total de personnes ayant une éducation primaire, secondaire et supérieure était d'environ 98\%. Un ménage moyen comptait environ cing personnes dans la zone d'étude.

Mots clés: COVID-19, pandémie, chaîne de valeur, sous-secteur de la volaille, vente de dé

\section{Introduction}

The ongoing corona-virus pandemic (COVID-19) has been a public health emergency all over the world which becomes more important for a developing and also populous country Nigeria, notably called Giant of Africa with a population of over 180million. COVID -19 Came to Nigeria on the $27^{\text {th }}$ February 2020. The enforcement of many phase and different shades of lockdown, its total and partial lockdown has been a new experience for everyone. Agriculture accounts for $35 \%$ of Nigeria's GDP before the ascendancy of oil; agriculture was the country's major earner of foreign currency. Now the oil is on a decline, there is a great clamor for diversification of the Nigerian economy. This has redirected attention to agriculture and now the government of Nigeria is paying unprecedented attention to agricultural development- both as an instrument for reducing the nations import bill and as a potential leading source of foreign currency. Livestock and poultry have been an important subsectors of agriculture in Nigeria contributing 450 GDP in $2017-2018$ and providing livelihood and employment to about $7.9 \%$ population in the country with a population of 5464million livestock and 876million poultry, the sector has been the major provider of animal protein in the country, thereby significantly contributing to nutritional security of all age groups. The Nigeria poultry industry contributes approximately $25 \%$ to agricultural GDP. Nigeria has the largest annual egg production and second largest chicken population in Africa. The Nigeria poultry industry comprises about 180 million birds, of these 80 million chickens are raised in extensive, 60 million in semi intensive and the remaining 40 million in intensive. Poultry production in Nigeria amounts to $300 \mathrm{Mt}$ of meat and $650 \mathrm{Mt}$ of eggs per year. About 85 million Nigerians are involved in 


\section{Akure, Vantsawa, Balogun, Omodona, Emeghara and Olafemi}

poultry production (many on a small to medium scale). The impact of COVID-19 and the associated lockdown on livestock and poultry sector in the country during this period has been phenomenal. It is further envisaged that the impact would continue to be long standing and will have great bearing on the livelihood, employment and overall economy of the sector, while all associated issues are being addressed with a strong might in these days, a holistic understanding of the overall impact would help in drawing appropriate policies and revival strategies. Inadequacy of countrywide information on relevant aspects has been a major problem for having a better understanding of the impact of the pandemic and the prolonged lockdown on different sub sectors of livestock and poultry. It is in the light of these therefore, that this study attempted to provide answers to the following research questions; what are the socio-economic characteristics of respondents $\square$ What are the impacts of the pandemic on the farmers $\square$ How many broiler chickens were lost $\square$ What were the constraints faced by farmers during the lock down $\square$

\section{Methodology}

Studyarea

The study was carried out in Kano State. Kano state is located in north western Nigeria. It occupies an area approximately $20,131 \mathrm{~km}^{2}$. It is located on latitude $11^{0} 55^{\prime} \mathrm{N}$ and longitude $8^{0} 36^{\prime} \mathrm{E}$ with an average altitude of $484 \mathrm{~m}$ above sea level (KNARDA, 2011). The State has a population of totaling 9,383,628 according to 2006 National Population Census (NPC, 2006). Kano State borders Katsina State to the North-West and Jigawa State to the Nnorth-east. Farming is the main occupation of the people and it is characterized predominantly by mixed cropping. Kano State features savanna vegetation with a semi-arid climate. It witnesses an average precipitation of about $690 \mathrm{~mm}$ per year, the bulk of which falls from June to September. The state is typically hot throughout the year, though noticeably cool from December to February. The annual temperature ranges between $19.06^{\circ} \mathrm{C}$ to $33.19^{\circ} \mathrm{C}$. It has a welldrained ferruginous soil. Subsistence and commercial agriculture is mostly practiced in the State. Among the food crops cultivated are millet, cowpeas, sorghum, maize and rice for local consumption while groundnuts and cotton are produced for export and industrial. Poultry production is also widely practiced (many on a small to medium scale). Kano state has forty four local government area and Faggae Local government Area is considered for the study.

\section{Sampling technique and data collection}

Primary data were sourced to achieve the various objectives of the study. A multistage sampling technique was used to select two hundred respondents for this study. The first stage involves the purposive selection of faggae local government area. It is an area notable for high concentration of many tribes that are involved in poultry production. This was followed by a random selection of five wards in faggae Local Government Area namely, no-mans-land, sabongari, kurna, kwakwaci and faggae central after which 200 poultry farmers were purposively selected based on the record of farming/poultry activities. Structured questionnaires were used to collect data on socio- economic characteristics, impact of COVID-19 and constraints

\section{Method of data collection and analytical techniques}

Primary data was used for the study. This was obtained by administering structured questionnaire to poultry farmers in the study area by trained enumerators. A total of 200 farmers were used for the study.Data were collected on socio-economic variables (age, 


\section{Impact of COVID-19 and associated lockdown on livestock and poultry sector}

educational level, marital status farm size, farming experience, and non farming activities of the respondents). Information was also collected on the input-output level, income and expenditure of the respondents. Descriptive statistics (including frequencies and percentages) and inferential statistics were used to describe the socio-economic attributes of the respondents.

Descriptive statistics (such as mean, frequency distribution and percentage) and Likert scale were employed to achieve the objectives of the study.

\section{The Likert scale}

The constraint encountered by the poultry farmers at the heat of the COVID-19 pandemic was measured by a given set of perception questions to respondents. Their responses were recorded using the five point Likert Scale of strongly agree (SA), agree (A), undecided (U), disagree (D) and strongly disagree (SD). These were scored $5,4,3,2,1$, respectively

\section{Perception measurement}

SA- Strongly agree (5points)

A-Agree (4Points), U- Undecided (3Points) D- Disagree (2 Points), SD- Strongly disagreed (1point).

In order to rate the perception of respondent's constraints the total raw score of the respondents using the five- point Likert Scale is represented as: The mean was calculated for each of the constraints $\frac{5(\mathrm{~N})+4(\mathrm{~N})+3(\mathrm{~N})+2(\mathrm{~N})+1(\mathrm{~N})}{\mathrm{S}}$

Where;

$\mathrm{N}=$ Number of respondents in respect to their identified level of constraints

$\mathrm{S}=$ Total sample size of sampled households

\section{Decision rule}

The mean score of respondents below 4.60 (0-4.59) was considered as negative (i.e not a constraint) while the mean score above $4.60(>4.60)$ was considered positive (i.e. a constraints) for the study.

\section{Results and discussion}

Socio-economic characteristics considered in this study are presented in Table 1 . The study revealed that the sampled household had a mean age of 29 years. Most of the respondents were aged between 21-30 years. This age group makes up about 58\% of the total sampled respondents, although the mean age of the respondents was 29 years, $22.5 \%$ of them were aged between 31-40 years old, these attributes show that the sampled respondent are youths furthermore, most of the respondents $67.5 \%$ were female while 32.5 were male. These showed that more women participate in poultry farming. Furthermore, most of the sampled respondents were educated with $52 \%$ having attained tertiary education. On marital status, the distribution shows that $74.00 \%$ of the respondents were married adults and $16.0 \%$ are single, $8.00 \%$ widow and $2.00 \%$ divorced. About $83 \%$ of the sampled respondents were on poultry farming full time. The implication of this is that their sole source of income was grossly affected. $9 \%$ were civil servants and $6 \%$ were traders. The mean household size for the area was 5, majority $(59.0 \%)$ of the respondents have household size of about 15 persons per family, however $30.00 \%$ had between 6-10 household members and about 3\% had between 11-15 persons per family. The year of experience of the respondents in poultry farming varies. The largest percentage $(84.5 \%)$ of the respondents had been in poultry farming for a long period of more than 10 years, implying that the poultry farming has been able to support their livelihood for a long time and they have been through the poultry farming for long so it may be difficult to leave the farming for another new field or trade entirely. 
Table 1: Socio-economic variables of respondents

\begin{tabular}{|c|c|c|}
\hline Variables & Frequency & Percentage \\
\hline \multicolumn{3}{|l|}{ Age } \\
\hline $10-20$ & 24 & 12.0 \\
\hline $21-30$ & 115 & 57.7 \\
\hline $31-40$ & 45 & 22.5 \\
\hline $41-50$ & 21 & 10.5 \\
\hline $51-60$ & 8 & 4.0 \\
\hline Mean age & 29 & \\
\hline \multicolumn{3}{|l|}{ Gender } \\
\hline Male & 65 & 32.5 \\
\hline Female & 135 & 67.5 \\
\hline \multicolumn{3}{|l|}{ Level of education } \\
\hline Primary education & 22 & 11.0 \\
\hline Secondary education & 73 & 36.5 \\
\hline Tertiary education & 100 & 50.0 \\
\hline \multicolumn{3}{|l|}{ Marital } \\
\hline Single & 32 & 16.0 \\
\hline Married & 148 & 74.0 \\
\hline Divorced & 4 & 2.0 \\
\hline widow & 16 & 8.0 \\
\hline \multicolumn{3}{|c|}{ Occupation distribution } \\
\hline Trader & 12 & 6.0 \\
\hline Poultry farmer & 166 & 83.0 \\
\hline Civil servants & 18 & 9.0 \\
\hline Others & 4 & 2.0 \\
\hline \multicolumn{3}{|l|}{ Household size } \\
\hline $1-5$ & 118 & 59,0 \\
\hline $6-10$ & 60 & 30,0 \\
\hline $11-15$ & 20 & 10,0 \\
\hline$>15$ & 2 & 1.0 \\
\hline \multicolumn{3}{|l|}{ Mean age } \\
\hline \multicolumn{3}{|l|}{ Years of experience } \\
\hline $1-5$ & 8 & 4.0 \\
\hline $6-10$ & 20 & 10.0 \\
\hline $11-15$ & 169 & 84.5 \\
\hline$>15$ & 3 & 1.5 \\
\hline
\end{tabular}

Source: Field survey, 2020

Table 2 reveals the operational status of the various farms in the study area. One of the major effects of -COVID-19 in the year 2020 was closure of some broiler farms in Kano, Nigeria. Some of the reasons for the closures gathered by the farmers were shortage of human resources, inability to even pay for the few workers that were remaining on farm, lack of moneyand high cost of feed amidst many factors, From the result $12.5 \%$ of the respondent farms permanently closed between June and July. $35 \%$ of the farms reopened as from august till date and just barely half of the total farm never shut down, may be they had labour who were resident in the farms and it is also 


\section{Impact of COVID-19 and associated lockdown on livestock and poultry sector}

possible that such farms had reserve feed and feed ingredients. Those farms that remain temporarily closed are probably those with resource to reopen quickly. Table 3 shows the number of broiler chickens produced during some of the selected festive period in 2020. The production of broiler chicken in 2020 was very low compared to the supply in 2019. In 2019 a total of 600 thousand broilers were raised, while in 2020, only a total of 305 thousand broilers were raised by the respondents, their reasons being high price of the day old chicks which became unaffordable by some of the farmers, those of the farmers who could afford to buy could not buy as much as they use to buy, for lack of capital and poor cash flow. Apart from the Easter period, there was significant reduction for all the festive period examined. A total of close to $50 \%$ gross reduction in production was recorded.
Table 4: shows the total net worth and the cash flow from broiler farms during the selected festive period within the year. Many broiler farms are facing cash constraint problems. There was significant reduction for the total net worth throughout the selected festive period in 2020 except for the Easter, this could be because most of the farms had stock in their farms before the total lock down and they were equally able to sell their chickens as and when due. The gross reduction in the net worth of broiler produced within the period examined amounted to $51.1 \%$.

Table 5 shows the percentage of workers reducedby the respondents. The total workers hired by the surveyed broiler farms decreased by 43.5 between September 2019 and June 2020 - from 1600 to 680 Reductions in the work force came from both closed and operational farms. The percentage reduction amounted to $57.5 \%$.

Table 2: Effects of COVID-19 on operational status of broiler chicken farms

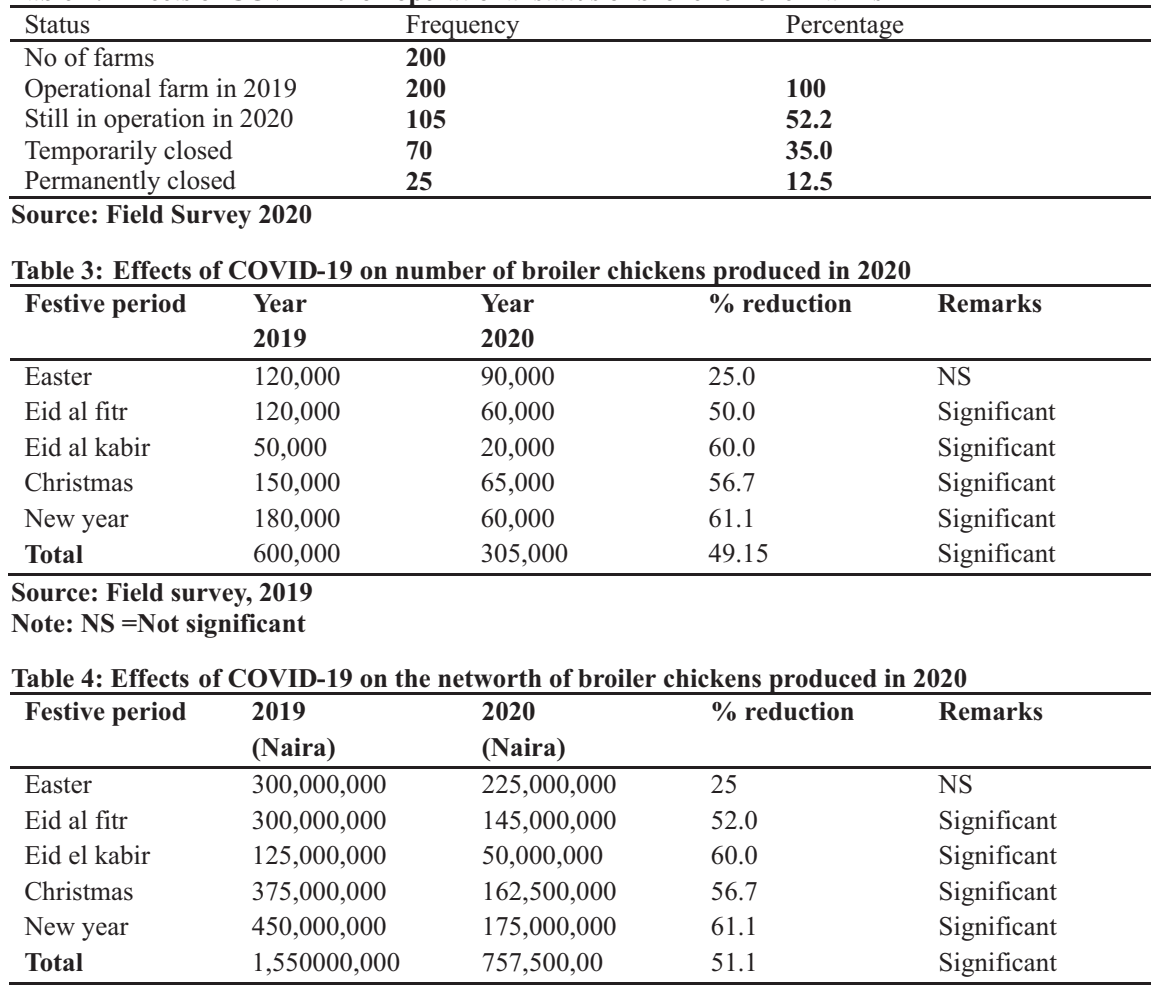

Source: Field survey, 2019

Note: $<\mathbf{5 0} \% \mathbf{N S},>\mathbf{5 0} \%=$ Significant, $\mathbf{N S}=$ Not significant 
Akure, Vantsawa, Balogun, Omodona, Emeghara and Olafemi

Table 5: Effects of COVID-19 on number of farm workers in 2020

\begin{tabular}{llll}
\hline Parameters & $\mathbf{2 0 1 9}$ & $\mathbf{2 0 2 0}$ & \%Reduction \\
\hline Permanent staff & 800 & 400 & 50.0 \\
Part time staff & 500 & 200 & 60.0 \\
Visiting staff & 300 & 80 & 73.3 \\
Total & 1600 & 680 & 57.5 \\
\hline Source: Field survey, 2019
\end{tabular}

Table 6 shows the prioritization of the constraints to the broiler farmers during the study.

The most serious constraints to broiler production in the area was the expensive feed with a means score of (4.94). This finding agrees with those of Akure (2013) and Akure et al. (2020) in their study that feed in broiler constitute over $70 \%$ of the cost of production of broiler chickens Logistics interruption ranked second most serious constraint with a mean score of (4.83) was considered. Labour shortage ranked third most serious constraint with a mean score of (4.82) was considered. Movement restriction ranked fourth most serious constraint with a mean score of (4.75) was considered. Non-payment of salary ranked fifth most serious constraint with a mean score of (4.70) was considered. The only variable that was not a constraint was the death of staff with a mean score of 3.20 was considered.

Table 6: Constraints faced by broiler farmers during COVID-19

\begin{tabular}{|c|c|c|c|c|c|c|c|c|c|}
\hline VARIABLE & SA & AG & UD & DA & SD & $\begin{array}{l}\text { TOTAL } \\
\text { SCORE }\end{array}$ & $\begin{array}{l}\text { MEAN } \\
\text { SCORE }\end{array}$ & RANKING & REMARKS \\
\hline $\begin{array}{l}\text { Movement } \\
\text { restriction }\end{array}$ & 167 & 23 & 3 & 6 & 1 & 949 & 4.75 & $4^{\text {th }}$ & $\begin{array}{l}\text { It is a } \\
\text { constraint }\end{array}$ \\
\hline $\begin{array}{l}\text { Labour } \\
\text { shortage }\end{array}$ & 170 & 25 & 3 & 2 & 0 & 963 & 4.82 & $3^{\text {rd }}$ & $\begin{array}{l}\text { It is a } \\
\text { constraint }\end{array}$ \\
\hline $\begin{array}{l}\text { Logistics } \\
\text { interruption }\end{array}$ & 168 & 30 & 2 & 0 & 0 & 966 & 4.83 & $2^{\text {nd }}$ & $\begin{array}{l}\text { It is a } \\
\text { constraint }\end{array}$ \\
\hline $\begin{array}{l}\text { Expensive } \\
\text { feed } \\
\text { animals }\end{array}$ & 189 & 11 & 0 & 0 & 0 & 989 & 4.94 & $1^{\text {st }}$ & $\begin{array}{l}\text { It is a } \\
\text { constraint }\end{array}$ \\
\hline $\begin{array}{l}\text { Lack of } \\
\text { access to feed }\end{array}$ & 154 & 32 & 7 & 5 & 2 & 931 & 4.65 & $6^{\text {th }}$ & $\begin{array}{l}\text { It is a } \\
\text { constraint }\end{array}$ \\
\hline $\begin{array}{l}\text { Death of staff } \\
\text { members }\end{array}$ & 86 & 52 & 32 & 25 & 5 & 789 & 3.20 & 7 th & $\begin{array}{l}\text { Not a } \\
\text { constraint }\end{array}$ \\
\hline $\begin{array}{l}\text { Non-payment } \\
\text { of salary }\end{array}$ & 161 & 25 & 7 & 5 & 2 & 938 & 4.70 & $5^{\text {th }}$ & $\begin{array}{l}\text { It is a } \\
\text { constraint }\end{array}$ \\
\hline
\end{tabular}

Source: Field survey, 2019

\section{Conclusion and recommendations}

This study was carried out to assess the impacts of the pandemic on poultry farmers $\square$ How many broiler chickens were lost and the constraints faced by poultry farmers during the lock down in Faggae Local Government Area of Kano State.
Descriptive statistics and 5 point likert scale were used to analyze the data. The study showed that most of the respondents were young (with mean age of 29years) who are very energetic in carrying out poultry farming, about $74 \%$ of the respondents are married and $67.5 \%$ of them were females. 
COVID-19 had a negative impact on all the activities related to broiler production ranging from low production to low cash flow, high cost of feed and lots more. High cost of feed represented the most serious constraint with a mean score of 4.94 . The study recommends that farmer's cooperatives should be involved in helping farmers organize group sales and to get exemptions to movement restrictions to ensure the flow of food and feed materials and production related goods and services to get better bargain for their products. The government should give expanded income support to affected farms and participation in government credit guarantee schemes and tax deferrals till 2021

\section{References}

Akure, C. O. 2013. Evaluation of the nutritive value of differently processed Mucuna pruriens seed meal $(\mathrm{msm})$ on the performance of broiler chicken. PhD Dissertation submitted to the Department of Animal Science, Faculty of Agriculture. Ahmadu Bello University Zaria, Kaduna State, Nigeria.
Akure, C. O., Sekoni, A. A., Abeke, F. O., Vantsawa, P. A., Babasanya, B., Olukotun, O. and Ayodele, J. T. 2020. Growth performance and carcass characteristics of finisher broilers fed fermented mucunapruriens seed meal. Journal of Animal Production Research, 32 (1): 92-99.

Kano State Agricultural and Rural Development Authority (KNARDA) 2011. Weather Station.

National Planning Commission, Nigerian Economy, 1st Half (2010).

Received: $12^{\text {th }}$ October, 2020 Accepted: $5^{\text {th }}$ February, 2021 